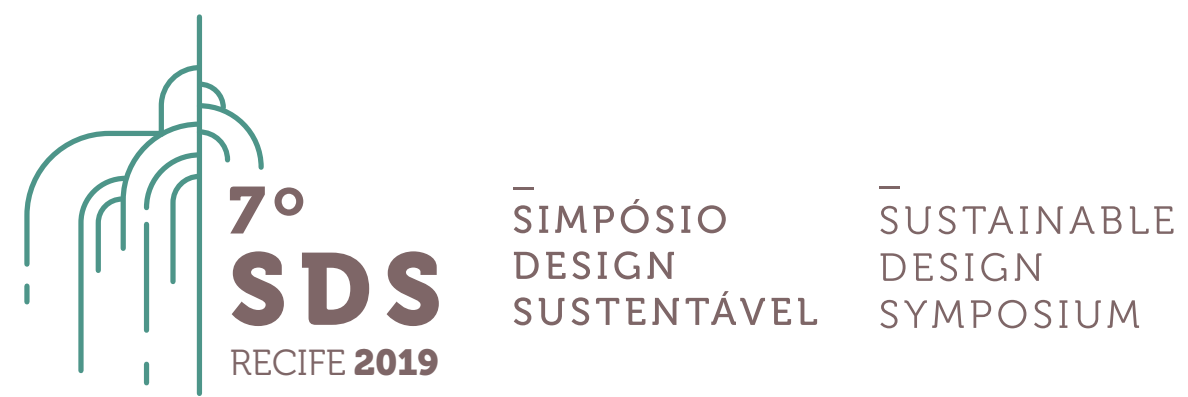

\title{
Experiences within the furniture sector in Brazil: design and sustainability at the basis
}

\author{
Viviane dos Guimarães Alvim Nunes ${ }^{1}$ \\ ${ }^{1}$ Federal University of Uberlândia/MG/Brazil, PPGAU/FAUED, viviane.nunes@ufu.br
}

\begin{abstract}
The reduction of environmental impacts demands a Design approach that embraces concept development, the use of pilot projects and the optimization of production techniques. Sustainable strategies must include collaboration and the exchange of knowledge, as well as the adoption of more efficient processes through design. This paper aims at discussing the experiences of Brazilian furniture micro and small enterprises (MSEs) that attempted to adopt these strategies. The first research discuss a design pilot project that had three main objectives: (1) to incorporate sustainable design concepts and practices in the manufacturing of wooden furniture, (2) to experiment with a serial production process, thus measuring the behavioral change of MSEs regarding production, and (3) to evaluate the level of collaboration among MSEs. The second research aimed to empower the enterprises, individually, based on the first research's recommendations. By focusing on specific aspects, this paper presents experiences and design concepts, as well as analyses the benefits and challenges for their implementation, regarding: Environmental solutions; Technological limitations; Economic issues; Socio-cultural and Organizational opportunities to strengthen relationships among companies, government, academic and support institutions, including the collaboration among researchers and society as a whole.
\end{abstract}

Keywords: inter-organizational collaborative networks; sustainable design strategies; Brazilian furniture MSEs; design pilot project.

\section{Introduction}

In the 1990's, sustainability movements were characterized by a small number of researchers and activists who had taken a whole-system approach to the challenge of developing human systems and technologies that offer high quality and environmentally healthy ways of life for humankind. However, this whole-system thinking must also include the awareness of the importance of interconnections, relationships, results and response circles (GILMAN, 1990; MANZINI, 2006) and closed cycles as established in Circular Economy principles (WEF, 2014; EEA, 2017). Thus, the shift toward sustainability is a social learning process because it counts on 
progressive efforts to achieve significant change. To succeed, it calls for a systemic discontinuity to give way to novel systems of production and consumption, and a highly context-related socialtechnical system. This transition requires the learning of living better lives through improving physical and social life contexts, thus resulting in new behaviors that consume significantly fewer natural resources (MANZINI; VEZZOLI, 2002; MANZINI, 2006; MORELLI, 2007; MANZINI, 2015).

From the perspective of designers, designing for sustainability is a strategic approach that aims to generate and develop sustainable solutions that yield results at three levels: economic growth, environment management and social progress (ELKINGTON 1994; MANZINI, 2006; MORELLI 2007). Thus, it is central to increase the sense of participation of all involved, boost visibility for the adoption of new solutions, and enable assistance, leadership and partnership opportunities for interested groups (industries, research and support institutions, civil society) towards change (GILMAN, 1990; HALL, 1995; MORELLI, 2007).

Even if traditional industry is moving towards more aggressive models of globalization, the operational strategies of companies are forced to take local contexts into account. Competitive advantages entail the development of innovations at the local level that focus on individuals. In contextualized scenarios, the new design agenda demands the precise use of capabilities to unlock innovative and successful social solutions. Designers need to create conditions to stimulate the abilities of the individuals who compose the systems, testing original ways of being and of acting in collaborative paths (MANZINI, 2007; MORELLI, 2007; BROWN, 2008).

\subsection{The transition towards sustainability}

Transition experiments are, therefore, a key concept to describe small-scale trials that can be used as mechanisms to support the evolution into a more sustainable society (LOORBACH, 2007; VAN DEN BOSCH; ROTMANS, 2008). In line with the concept of Pilot Projects and further broadening it, these trials are oriented by a wide-range of societal needs (that go beyond technological innovation) and cover a great variety of innovations, including institutional, legal, financial or social-cultural changes. Different instruments are employed in activities that occur at the operational, tactical and strategic levels. At the operational level, initiatives include the activation of actors, a set-up and a pilot implementation, with the goal of turning visions into concrete actions. At the tactical level, actions include planning paths for cooperation opportunities. The goals are to develop partnerships to attain stronger support and address the change. At the strategic level, experiments focus on creating a common understanding of the problem, a shared sense of urgency and a shared direction (MOZOTA; 2006; LOORBACH, 2007; VAN DEN BOSCH; ROTMANS, 2008).

\section{First research: Starting from a Design Pilot Project}

The MODU.Lares Pilot Project was carried out in a collaborative way as a strategy to trigger the evolution toward sustainability in a fragmented local system, which performed poorly in this arena. The project was a socially and environmentally relevant network-based experience, which engaged different types of organizations, such as wooden furniture MSEs, academic and support institutions and the local government. The experience occurred in Uberlandia/Brazil, a city situated in the Triângulo Mineiro and Alto Paranaíba region in the State of Minas Gerais, in Southeastern Brazil. The furniture sector of the micro region ${ }^{a}$ was formed by about 800 MSEs (OLIVEIRA et al. 2012), almost $85 \%$ of which are not officially registered, work with old machines, and generally offer low-quality products from a technical-productive standpoint; they also rely mainly on craft manufacturing processes and tailored products (SENAI et al., 2006). Most companies (both informal and formal) lack control over the selection and use of safe raw materials

\footnotetext{
${ }^{\text {a }}$ This micro region is formed by 9 small cities of which Uberlandia is the most important among them.
} 
as well as of waste disposal, which constitutes a serious environmental issue for the city.

Although few initiatives to modernize the local MSEs are noticed, much remains to improve their businesses, in particular their design concerns, and much larger investment is required to increment their productivity, quality and environmental awareness. Problems such as: 1) high production costs; 2) production limitations; 3) product pricing, directly affect their everyday work. There is a clear need for regionalized design policies to explore new opportunities which enhance efficiency in the region as a way to make them more competitive and sustainable. However, the increment in the quality of facilities depends on the availability of financial resources. As an alternative, collaborative works (and networks) are a viable strategy to gradually improve knowledge and skills, awareness of design and management issues, which can, therefore, contribute to the evolution of such companies (VAN DE VEN, 1986; KLOTH; APPLEGATE, 2004).

It is worth pointing out that, for stimulating innovation and local development, collaborative (net)works depend on the groups that integrate them, detailed instruments of coordination, and on the creation and re-creation of a circle of knowledge so that a common understanding (SWAN et al., 1999; LOPES; BALDI 2009) or a common language (CARLILE, 2002) can be shared. However, the effectiveness of sustainability as a competitive strategy demands the improvement of the abilities of each partner involved in the process, whether they are individuals or organizations.

\subsection{Developing design strategies through collaboration}

The adoption of design strategies by companies is subordinated to the development of broader strategic thinking within the organization (MOZOTA, 2003; BEST, 2006). These strategies, however, need to be integrated through a collaborative system (SCHNEIDER; INGRAM, 1990; SWAN et al., 1999) that visualizes all of the dimensions of the process and allows individuals and organizations to exchange knowledge and information. In this collaborative scenario, this Pilot Project proposed a new way to conceive, to produce objects, and to relate with other organizations to achieve better results for environmental, economic, technological, and sociocultural issues (MANZINI; VEZZOLI, 2002; HARDY, LAWRENCE; GRANT, 2005).

A modular furniture solution aimed at reducing raw material losses and waste generation and at optimizing the manufacturing process (MAXWELL; VAN DER VORST 2003; LUNBERG, 2005; VEZZOLI, 2007; FEDERLEGNO-ARREDO et al., 2010). Organizational and sociocultural aspects had been faced to push collaboration among companies so that they exchanged knowledge and information, and to support an integrated production process. The reorganization of MSEs is essential to restructuring relationships and to managing actions in a way that enables business results (VAN DE VEN, 1986; MOZOTA, 2003; MARCHICA, 2004; TOMAEL; ALCARA; DI CHIARA, 2005; BEST, 2006).

\subsection{Designing a more responsible and advantageous production process}

The design of the furniture collection was based on a simple assembly system and linear shapes, with few components and details. The series was composed of six objects: Chair, Bookshelf, Dinner table, Coffee table, two Multiple Use pieces and prototyped in a craft production system. Besides selecting non-toxic raw materials, the guidelines aimed to minimize waste generation (MAXWELL; VAN DER VORST, 2003; LUNGBERG, 2005), as follows: 1) reduce the use of different materials to simplify the process, thus fostering the recycling of waste and the reusing of components in the end of their lifecycle; 2) optimize the number of components and pieces, to simplify the assembly and combination of parts; 3 ) optimize the use of materials/minimize waste by adopting standard dimensions and simple geometry; 4) integrate functions or use a component in more than one way, thus reducing the consumption of raw 
material, work and energy; 5) select raw materials and processes with a low environmental impact (low levels of formaldehyde emission).

\subsubsection{Prototyping the pilot artifacts}

The whole Pilot was developed in two stages within an 18-month period: the first one (6 months long) aimed at creating partnerships and at checking the availability of MSEs; the second one (12 months long) defined a set of actions to serve as the compass for project development, including the design of the artifacts. The prototyping phase (from January 02 to January 26, 2012) was monitored by the researcher within the 8 selected MSEs and divided into two rounds: the production of mock-ups and prototyping. During the prototyping phase, some MSEs showed less interest in it: some objects did not come out as expected due to the short time available; others, due to many prototyping errors, needed to be redone more than once, thus requiring deadlines to be pushed further. Two artifacts were selected to illustrate the prototyping process: the bookshelf and the chair.

The Bookshelf was prototyped by Micro Enterprise (ME) A, with the participation of the owner of ME-D. The piece shown in figures 1 to 2 was prototyped following the original project, despite the difficulties in cutting specific parts (due to the lack of a computerized cutting machine). This step allowed dimensions, resistance, flexibility and functionality of use to be assessed. The waste was minimal: $98 \%$ of the panel was used in the production of an entire bookshelf . The piece underwent some adjustments - either technical or formal - to simplify production, improve finishing and structural resistance. However, the final result preserved the original idea of flexibility and adaptability of use, allowing shelves to be assembled according to the user's needs (figures 3 and 4). The owner of ME-A owner participated actively in the prototyping process, discussing and contributing to improve solutions and collaborate toward the results.

Figures 1, 2 and 3, 4-Mock-up and Final Prototype
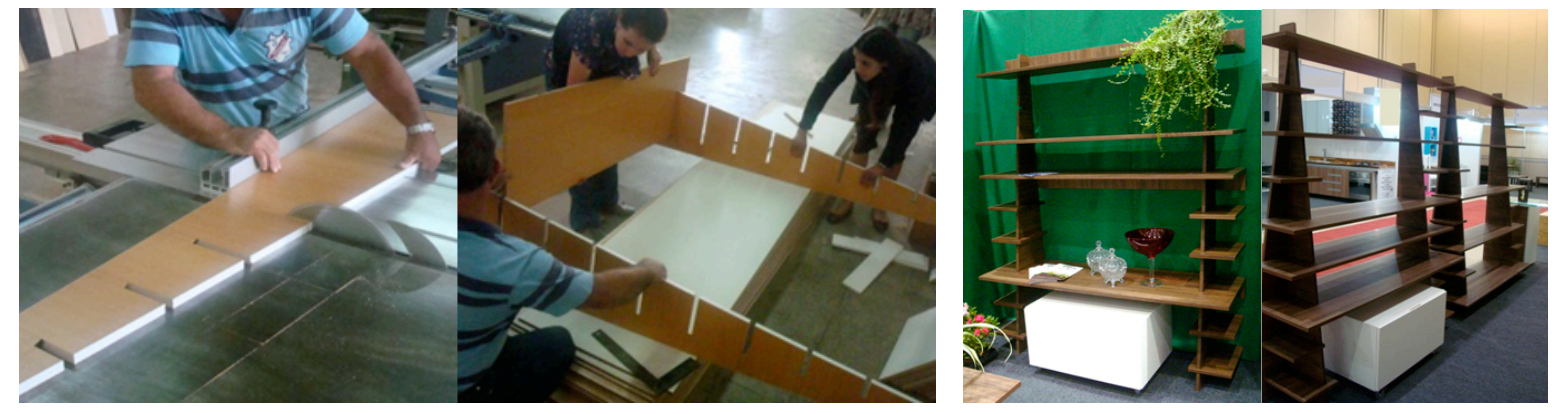

Fonte: Nunes (2013)

The Chair was prototyped by two companies (an artisanal process versus a CNC machine). The piece shown in figures 5 and 6 was craft-made and adapted due to the limited machinery available. The parts that had been originally designed to be single pieces had to be cut into smaller pieces and required additional assembly efforts. Although this change demanded more time to cut and fix, it made the manufacturing and finishing processes easier, and contributed to further optimizing the consumption of raw material and increasing the resistance of the object. The waste generated was minimal: $95 \%$ of the wooden panel was used to produce six entire chairs.

Minimal size adjustments were made in order to produce better ergonomics, thus making the chair more comfortable to the final user. The enterprise's owner was a proactive participant during the whole process, contributing to effectively improve the prototyping results. 
Figures 5, 6 and 7, 8-Artisanal and digital fabrication of the chair
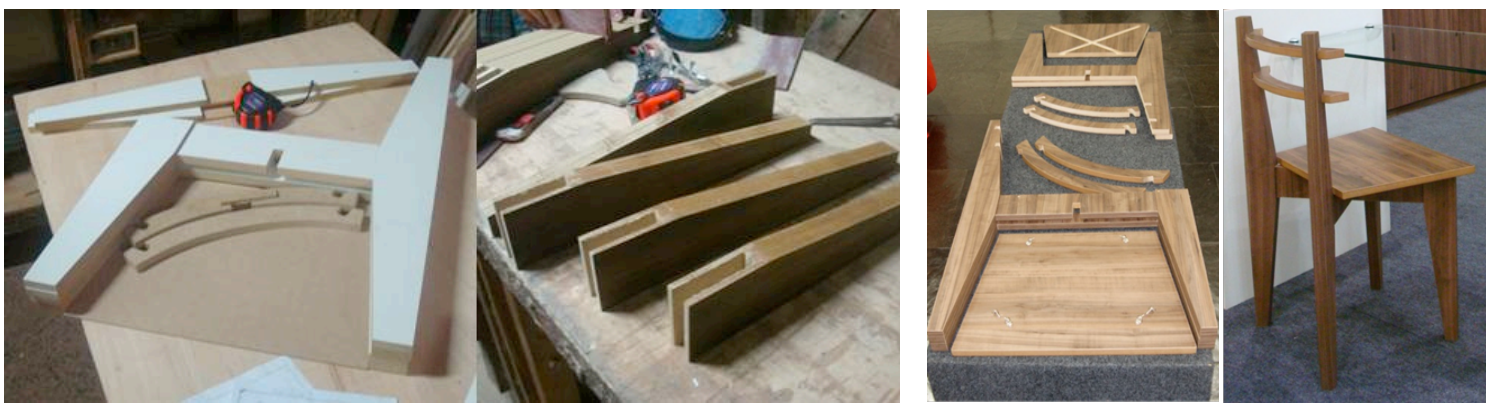

Fonte: Nunes (2013)

\subsubsection{The assessment of the pilot project}

As previously stated, an assessment model was developed within the broader scope of the research. Its prime objective was to evaluate the outcomes of the Pilot Project and, furthermore, to provide a tool capable of evaluating similar experiences involving other enterprises in the future and allow the trial to gain scale. The model was divided into five criteria (environmental, technological, economic, organizational and sociocultural), which aimed to evaluate aspects such as the quality of relationships, environmental and economic benefits, and adaptation to technological limits through proper design. The parameters were first listed in five major themes, and then detailed in closer points. Each topic was assigned a weight according to its relative importance, which produced a systematic and balanced measuring tool.

The analysis of the existing situation was based on two sources: for manufacturing matters (environmental, technological, economic aspects), a piece of furniture whose production was common to all enterprises (i.e. a 'standard' wardrobe) was used as a reference point; in respect to relationships and customer service aspects (organizational, socio-cultural issues) the assessment was based on the surveys carried out before and after the pilot. The evaluation (and the summary of criteria) allowed for the creation of a final map (a radar) so the results could be more clearly visualized (figure 9).

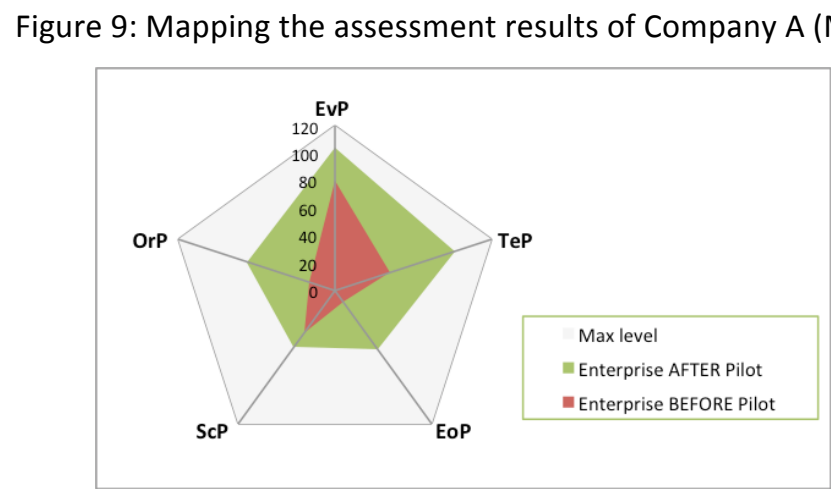

Fonte: Nunes (2012)

\subsection{Analyzing the outcomes of the Design Pilot Project}

The engagement of individuals and organizations in collaboration-driven partnerships depends on several conditions and intents. The more effective the involvement, the more promising the results associated with an experience are, since the actors work in tandem with each other (TSAI, 2009). Nevertheless, some conditions can also negatively affect the whole collaborative-network-building process. In such situations, as it is the case of this Pilot Project, 
continuous efforts and new strategies are needed so that the most favorable results can be achieved. In this respect, it is worth noting that the phases where potential partners were contacted and effective partnerships were established constituted the most demanding steps of the project, not only due to the several organizations that had to be pursued as potential partners, but also to the MSEs themselves.

There are many conditions that jeopardize engagement and collaboration among organizations: they can be found in the relationships among organizations of the same type, but they are equally prevalent in relationships among different types of organization. Issues that prevent collaboration include: 1) Lack of interest in making a coordinated effort to solve a problem as a group (BRNA, 1998); 2) Communication problems (BURTON, et al., 1997; BRNA, 1998); 3) Little social or professional relations among parties, which constitute the basis for trust, transparency and belief in mutual efforts to achieve collective goals (KLOTH; APPLEGATE, 2004; HOCEVAR et al., 2011); 4) Commitment to the individual responsibilities each participant must take on within the whole task (BRNA, 1998); 5) Difficulty of adopting both continued practices and changing internal policies to share responsibilities with others over whom the organization has no direct influence (KLOTH; APPLEGATE, 2004) - even indirect influence is quite relevant; 5) Trouble defining common goals, values and procedures (PAREEK, 1981; KLOTH; APPLEGATE, 2004); 6) Poor ability to visualize the interconnected system of interdependent actions (ELKINGTON, 1994; SACHS, 2002; MANZINI, 2006) that generate positive or negative cause/effect reactions.

All these arguments were identified during the Pilot development. Notwithstanding the efforts dedicated to establishing the collaborative network, the evident lack of engagement of relevant partners - i.e. local government, other associations and NGO - hindered, to a certain extent, the achievement of a higher level of sustainability and innovation in the local context.

\section{Second research: Fostering sustainable development within the furniture sector}

Built on the results of the first research and considering that the sector continued to face many organizational, managerial and leadership problems, this second research reported in this paper was carried out between 2015 and 2016. Its main objective was to update crucial sectoral data in order to support the proposition of tailored solutions to the firms, which could increase the positive socio-environmental impacts and, consequently, promote economic improvements. The methodology was broken into the following steps: literature review, mainly related to Strategic Design for sustainability; data collection, systematization and analysis; field research; elaboration of a document summarizing design management strategies for each enterprise partner as well as a Best Practices Guide to be shared across the whole sector. The research counted on the collaboration of six undergraduate students (scientific initiation scholarship recipients) who worked in all phases, from data collection to the production of final documents.

At first, the research selected 25 microenterprises to take part in the work; from this total, only 13 effectively collaborated in all activities during the course of the research. In a general view, the summary document was prepared based on the following topics: abstract of the research containing its objectives; characteristics of the 13 partner enterprises (ex. location, production processes, waste management); pictures of the enterprises; the synthesis of a SWOT analysis and of the assessment of aspects such as: Design, Infrastructure, Technological Resources, Economic Resources, Human Resources, Environmental Issues, and the conclusion.

\subsection{The Strategic Design for Sustainability approach}

Strategic Design has been evolving from a project-oriented activity based on interdisciplinary competencies aimed at formulating entrepreneurial strategies, towards a more 
systemic view (MANZINI; VEZZOLI, 2002; MERONI, 2008). This new vision considers social and economic actors as well as interactions between individuals and the environment. The main advantage the current paradigm is that it crosses the borders of organizations in order to achieve more comprehensive and positive outcomes that go beyond plain competitive advantage (VAN DE VEN, 1986). Indeed, the survival of an organization has been seen not just as a matter of advantage against competitors, but also as an feat of sustainability in relation to the system that surrounds the organization. This collaborative system can provide a positive environment for sustainability, enabling the creation of new sustainable values for all business processes. To exist, however, this system requires collaborative efforts from several actors such as enterprises, academic and support institutions, government and society, as established in the previous research.

Furthermore, design thinking uses the methods and the ability of designers to match the needs of people with what is technologically feasible. Since leaders see innovation as a fundamental source of differentiation and competitive advantage, organizations and companies must make an effort to incorporate design into all phases of the process (BROWN, 2008; MEO, 2012), moving it "backward from the earliest stages of a product's conception and forward to the last stages of its implementation" (BROWN, 2009, p. 148).

Magalhães (1994) and Brown (2008; 2009) reinforce the importance of having designers since the early stages of the innovation process, because it allows ideas to be explored more quickly. Many authors underline that: 1 ) the first strategic role of design is to investigate new issues and that is where its problem-setting (ZURLO, 1999; ZURLO, 2012) or problem-seeking (BEST, 2006) - therefore problem-solving, methodological and process-drafting - capacity stems from; 2) Building scenarios is a way to share visions, transforming evidence and perceptions into knowledge and resource for creation. As an inductive way of dealing with problem solving (ZURLO, 1999; MERONI, 2008; ROSSI FILHO, et al., 2009), design inspires new visions through practices and design tools; 3) Design is valued because it concretizes customer information and facilitates the participation of all company levels (MOZOTA, 2003; BEST, 2006);

\subsubsection{Field research: data collection from questionnaires and in loco visits}

The collection of data occurred via questionnaires, in loco visits and in-person/online contacts. The update of data was the most challenging phase due to the lack of systematized data on the subject. Starting from an existing number of 800 furniture MSEs in the Triângulo Mineiro microregion (OLIVEIRA et al., 2012), the initial research (2015-2016) identified 264 MSEs, but their current status could not be confirmed. A further investigation (2017) identified 172 additional MSEs, which brought the total up to 436 MSEs (both formal and informal ones), in the city of Uberlândia alone. Beyond the lack of any systematized data on the microenterprises, it is worth mentioning the scarce collaboration of professionals and suppliers, but mainly the nearly inexistent support from the Union of Furniture Manufacturers. Due to this, searches were done on the Internet and with the support of individuals, who helped with consolidating the pieces of information.

The questionnaires and visits were directed only to the de facto partners in this second research. The questions encompassed three main aspects: 1) Management Issues; 2) Infrastructure; and 3) Waste Management. This step was combined with fieldwork, when images were collected to support further analysis. The SWOT analysis was based on six categories, as follows: 1) Design: related to the way the microenterprise adopts design in its daily practices; if design is used to conceive products, as a management and/or marketing tool; 2) Infrastructure: related to the work environment (e.g. space, illumination, ventilation); the use of powder collectors, production flow, accessibility; 3 ) Economic resources: related to the resources to invest 
in technological manufacturing machinery, infrastructure and communications; 4) Technological resources: related to the use of digital resources to design better products, to plan and to optimize production processes (thus reducing waste and time), to calculate both the amount of material used and waste generation; 5) Human resources: related to the specific competencies to deal with management, design, manufacturing; 6) Environmental issues: related to the specific knowledge oriented to sustainability, waste management, reuse of waste, awareness of the National Solid Waste Policy (Law n. 12.305/10), correct destination.

\subsection{Outcomes of the second research}

As mentioned before, 25 microenterprises were selected to participate in the project; however, only 13 of them became effective participants. The outcomes of the fieldwork and the analysis of the answers to the questionnaires showed that, despite the small percentage of partner companies involved in the research, all of them share similar problems both in business management and in waste management. As for the number of employees, figure 10 shows that the majority of partners employ between 4 and 6 workers; figure 11 shows the typologies of production processes. Regarding management issues and human resources, the main problems are related to the unfair competition with informal companies, with 'similar' work and services but without guarantee and with lower prices due to tax evasion. This contributes to the closing of microenterprises and to the crisis in the sector. Since the 'informal' companies are afraid of their irregularities, most of the collected data is related to formal companies.

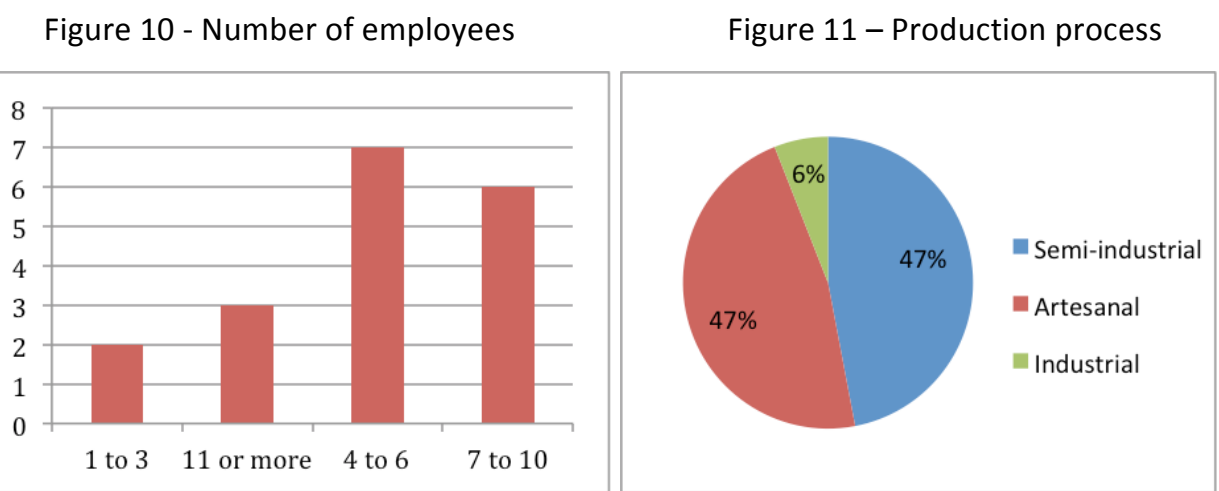

Source: Research data (unpublished, 2015/2016/2017)

Overall, figure 12 shows aspects of management, the understanding of the enterprise's mission and values, the level of satisfaction with the infrastructure. Figure 13 shows data related to human resources, including professional partnerships and other partners. Some entrepreneurs complained about the work of interior designers, who often focus on aesthetic solutions, and did not take the production processes into consideration. This is confirmed by the little detailed projects lacking specifications regarding materials, size and technical executive solutions, which cause many problems for carpenters/joiners at the time of manufacturing, which causes adaptations that had not been planned beforehand.

Regarding the production flow, most microenterprises follow a similar layout and certain logic in the machinery organization. However, in many of them, there is no method to classify small pieces of waste (which are still useful) and to separate them from solid waste (figure 14); some of them don't have powder collectors. 


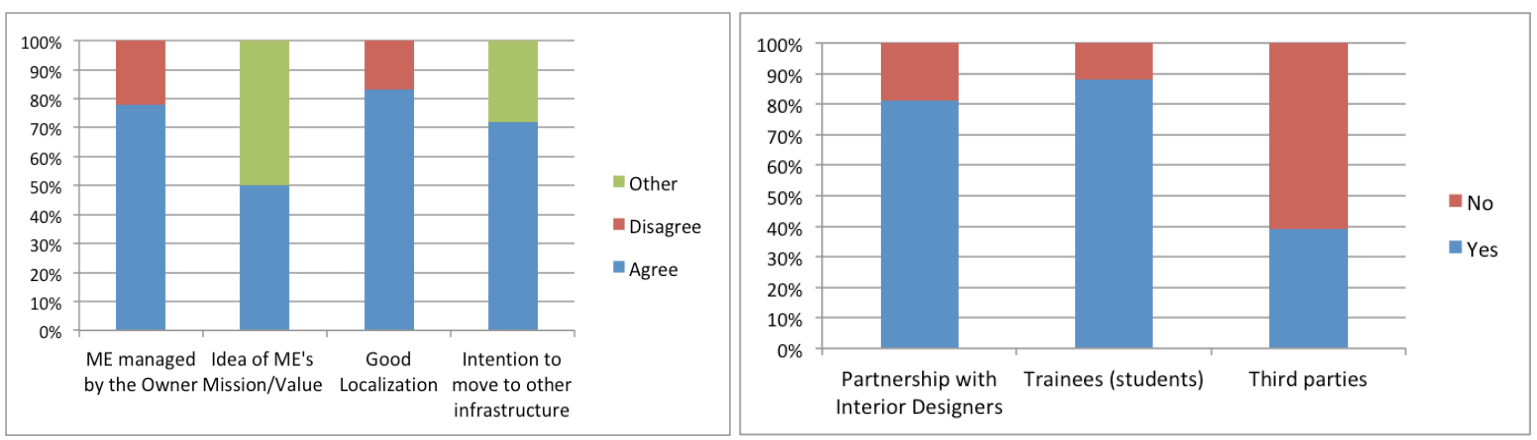

Source: Research data (unpublished, 2015/2016/2017)

As observed, most of the group adopts manual cut planning instead of a digital resource to better calculate the use of material, which partially explain the amount of waste generated during production. Moreover, the lack of a specific place to separate and keep pieces that can be reused also plays an important role in increasing material waste.

Figure 14 - Waste organization and disposal (in an ME)
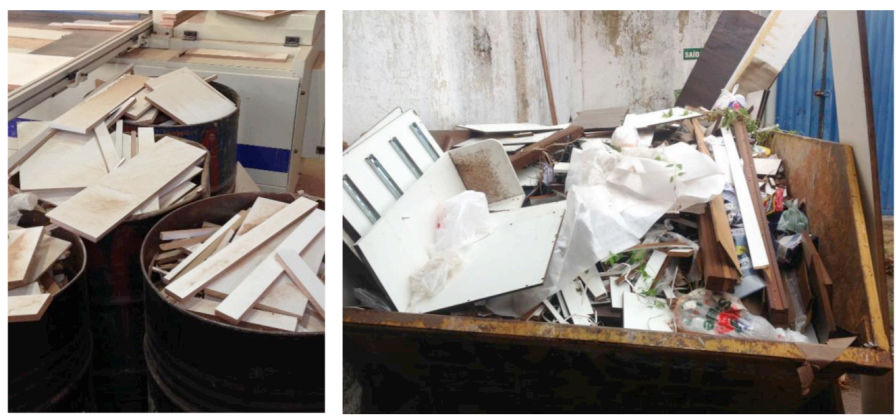

Source: Research data (unpublished, 2015/2016/2017)

The municipal powers are working to reduce waste disposal in inappropriate or forbidden places and issuing fines in order to prevent the increase in environmental problems. Due to this, many entrepreneurs have started partnerships with NGOs and other institutions to collect some kinds of useful or recyclable waste. In any case, almost all waste is disposed in the municipal landfill (figure 15).

Figure 15 - Amount of waste generated/month

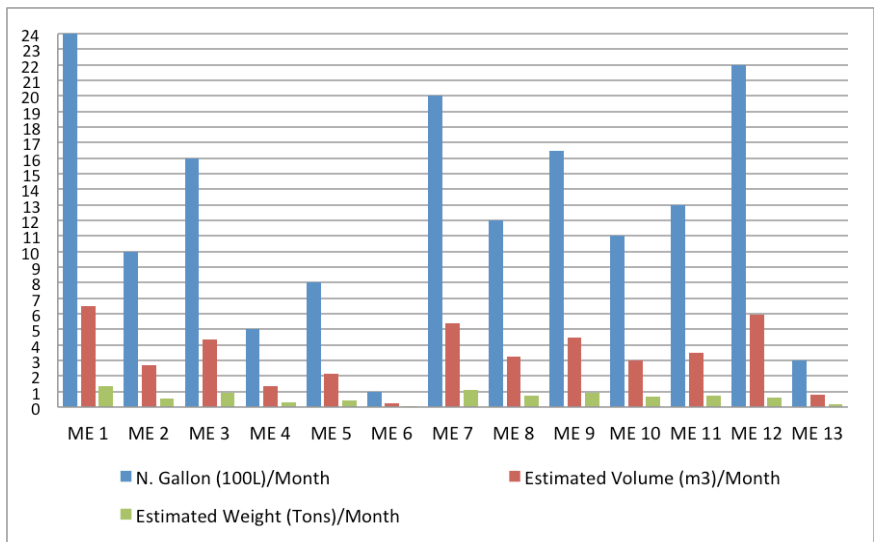

Source: Research data (unpublished, 2015/2016/2017) 
The most alarming issue is that is that some of the 'donated' waste is used as fuel ('coal') in the ovens of bakeries, pizzerias and others. This finding highlighted the lack of information about the toxic properties of the materials the microenterprises use as their main resources. All of those outcomes reinforce the urgent changes that must occur within the sector to help with the mitigation of environmental and health issues, mainly those associated with MDF products.

From the analysis of questionnaires and of the diagnosis, a document with preliminary strategies based on Strategic Design concepts was elaborated, containing solutions to be developed at three levels: operational (short term); tactical (planned actions); and strategic (a long term blueprint for the enterprises). Based on this, a first version of a Best Practices Guide (figure 16) was developed to lead the beginning of a process toward a more sustainable behavior by means of an easy read.

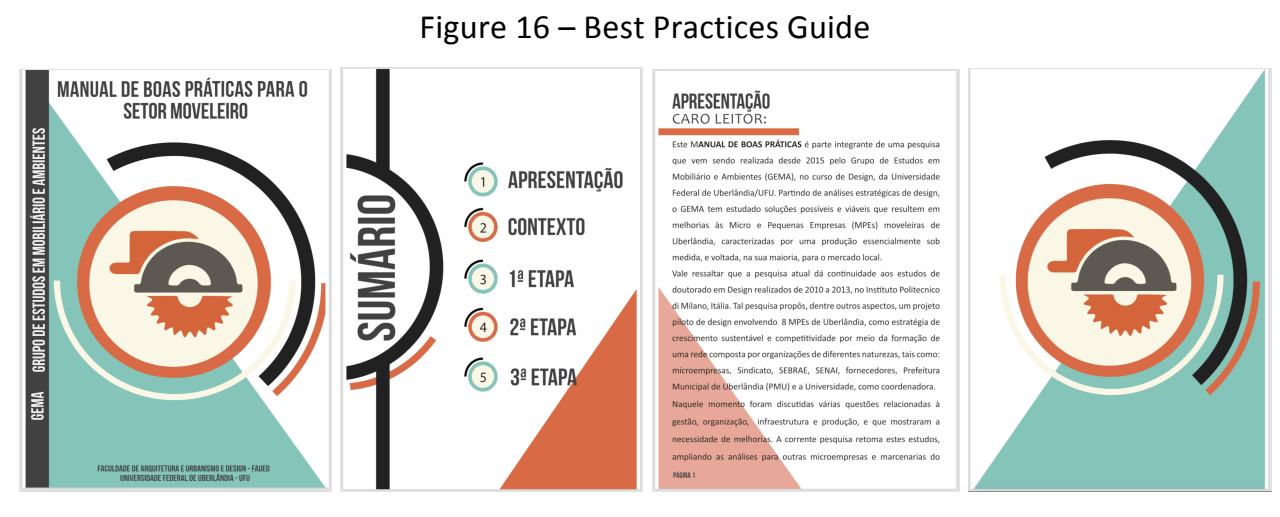

Source: ABRÃO (2017)

\subsubsection{Analyzing the outcomes of the research}

Different from the first described in this paper, this experience has contributed to improving the knowledge about the furniture sector, as it involved different partners, mostly ones that were less structured than the ones in the first group. This helped the group understand all the barriers enterprises face within the organization, not only those related to design adoption. However, changes in the local scenario depend on much more than individual efforts or researches due to the lack of economic resources to invest in infrastructure. Even if the enterprises assume (as they must) their responsibility on managing and controlling their waste, a systemic view needs to be adopted by the municipality. The effective participation of the Town Hall will provide conditions to encourage MSEs not only to collaborate, but also feed the system with the basic items necessary for a circular economy system to be established.

\section{Conclusion}

The outcomes of both researches confirm there is little interest from entrepreneurs in adopting new behavioral patterns and, as a result, new daily practices. This is worth highlighting, despite the difficulties faced by MSEs with improper waste disposal and the urgent need for solutions. In the first case, enterprises formed a small group that was invited to actively collaborate to provide results. In the second one, even though they were not committed to following the guidelines, there was little interest in knowing the results of the research: out of 40 companies invited to the meeting, only 5 participated in it. Not considering their own responsibilities regarding production, entrepreneurs often transferred them to the local government. This demonstrates once again their lack of familiarity with Law no. 12.305/10 that defines the National Policy on Solid Waste in Brazil and obliges companies to act responsibly in the production process and in the disposal of the waste generated from it. 
It is also important to mention that $90 \%$ of participating entrepreneurs in all researches did not know the physical-chemical properties of the raw material they used to produce furniture and the level of toxicity of panels when cut, burned, disposed in landfills and absorbed by the soil. As a whole, the researches confirmed the several managerial, organizational of local tailored production problems. It also revealed the lack of a systemic view of the business and of the sector, as well as the lack of commitment of the majority of them to collaborating to solve common problems. Another relevant issue is related to the lack of support from the Furniture Union (SINDMOB) but mainly from the local government (i.e., Town Hall) of Uberlândia, which has contributed to postponing the achievement of concrete and more comprehensive solutions.

The adoption of design thinking as a strategic approach to conceive and manufacture products, as well as manage companies is still a significant challenge. As the most part of the furniture projects are developed by interior designers and architects, the manufacturing is oriented towards the creation of unique products, without concerns about the assembly/disassembly processes, the use of safe materials or the production optimization. Most of the time, MSEs produce exactly what has been designed, without questioning or optimizing the solutions. This shows that the problem is intrinsically related to the professionals' awareness of the impact of their solutions.

When establishing new production models, strategic design also plays a role in awareness, thus contributing significantly with initiatives related to sustainability. In this context, Rocha and Brezet (1999) state that Strategic Design for Sustainability goes beyond the concepts concerning entrepreneurs/enterprises, encompassing other issues related to the Ecodesign and issues regarding the life cycle of products. Yet, this approach considers factors, such as "the incorporation of radical innovations that questions, for example, the real function of the product and the possibility of influencing the existing consumption patterns.

In 2016, the researcher started a new research project to investigate alternatives to the waste generated by the furniture sector that include Design Solutions for waste management, both related to reusing the useful waste and to developing new composites with it. We hope that, in the near future, the possibilities can be used to inspire new practices and foster more sustainable behaviors within the sector.

\section{References}

ABRÃO, Júlia S. Uso do Design para auxiliar no mapeamento e evolução do Setor Moveleiro de Uberlândia/MG. Relatório Final de Pesquisa de Iniciação Científica em Design. PIVIC. FAPEMIG2016- 0359. Orientador: profa. Dra. Viviane G. A. Nunes. Faculdade de Arquitetura, Urbanismo e Design (FAUeD). Universidade Federal de Uberlândia (UFU). Uberlândia, MG. 2017.

BEST, K. Design Management: Managing design strategy, process and implementation. Switzerland: AVA Publishing SA, 2006.

BURTON, M., BRNA, P. \& TREASURE-JONES, T. Splitting the collaborative atom: How to support learning about collaboration. In: B. BOULAY \& R. MIZOGUCHI, a cura di Artificial Intelligence in Education Knowledge and Media in Learning Systems. Amsterdam: IOS, pp. 135-142. 1997.

BRNA, P., Models of Collaboration. [Online] Available at: http://homepages.inf.ed.ac.uk/pbrna/papers/bcs98paper/bcs98.html [Accessed 17 December 2012]. 1998.

BROWN, T. Design Thinking. Harvard Business Review, June, pp. 1-10, 2008.

CARLILE, P., 2002. A pragmatic view of knowledge and Boundaries: Boundary Objects in New Product Development. Organization Science, Jul-Aug, 13(4), pp. 442-455. 
ELKINGTON, J. Towards the sustainable corporation: win-win-win Business Strategies for sustainable development. 1994

EUROPEAN ENVIRONMENT AGENCY. Circular by design Products in the circular economy. Luxembourg: Publications Office of the European Union. ISBN 978-92-9213-857-8 ISSN 1977-8449 doi:10.2800/860754. 2017

FEDERLEGNO-ARREDO, HABITEC, \& TRENTINO-SVILUPPO. Linee guida di interpretazione dei contributi del mobile rispetto ai crediti dello standard LEED 1 ed. Milano. 2010

GILMAN, R., (1990). Sustainability: The State of the Movement. The essential threads of who we are and where we're going. [Online] <http://www.context.org/ICLIB/IC25/Gilman.htm>, $14 / 11 / 2010$.

HARDY, C., LAWRENCE, T., \& GRANT, D. Discourse and collaboration: the role of conversation and collectivity identity. Academy of Management Review, 30(1), 58-77. 2005

KLOTH, C. \& APPLEGATE, B. Inter-organizational collaboration \& partnerships: a critical analysis, s.I.: Network Annual Conference. 2004.

LJUNGBERG, L. Materials selection and design for development of sustainable products. Materials and Design. Science Direct, 28, 466-479. 2005

LOORBACH, D. Transition management. New mode of governance for sustainable development. Rotterdam: Phd Dissertation, International Books. 2007

LOPES, F., \& BALDI, M. Redes como perspectiva de análise e como estrutura de governança: uma análise das diferentes contribuições. Revista de Administração Pública, 43(5), 1007-1035. 2009

MANZINI, E. \& Vezzoli, C. O desenvolvimento de produtos sustentáveis - os requisitos ambientais dos produtos industriais. Sao Paulo: Edusp. 2002

MANZINI, E. Design for sustainability. How to design sustainable solutions. [Online] <http://www.sustainable-everyday.net>, 15/05/2010. 2006

MANZINI, E. Designing networks and metadesign. Some introductory notes. [Online] <http://www.sustainable-everyday.net>, 15/05/2010. 2007

MANZINI, E. Design, when everybody designs.

MARCHICA, M. Reti Aziendali e problemi di finanziamento: teorie e ipostesi interpretative. In F. Cafaggi (ed), Reti di impresa tra regolazione e norme sociali. II Mulino. 2004

MAXWELL, D., \& van der Vorst, R. Developing sustainable products and services. Journal of Cleaner Production, 11, 883-895. 2003

Meroni, A. Strategic Design: where are we now? Reflection around the foundations of a recent discipline. Strategic Design Research Journal. 1(1), Jul-Dec, pp. 31-38. 2008.

MORELLI, N. Social Innovation and New Industrial Contexts: Can Designers "Industrialize" Socially Responsible Solutions? Design Issues v. 23, n. 4, Autumm, pp. 3-21. 2007

MOZOTA, B.B. Design Management using design to build brand value and corporate innovation. New York, NY: Allworth Press. 2003

NUNES, V. G. A. Design Pilot Project as a Boundary Object: a strategy to foster sustainable design policies for Brazilian MSEs. Milan, Italy: PhD Thesis in Design. INDACO Department, Polytechnic of Milan. Oct, 2013.

OLIVEIRA, P., ALVARENGA, A., PAES, F., FEITOSA, F., \& SILVA, J. Cadeia produtiva da movelaria: o 
polo moveleiro do Triangulo Mineiro. Viçosa/MG: EPAMIG. 2012, 44p.

PAREEK, U. Developing Collaboration in Organizations. University Associates Annual Handbook for Group Facilitators, pp. 165-182. 1981.

ROCHA, C. \& BREZET, H. Product-oriented environmental management systems: a case study. The Journal of Sustainable Product Design, Issue 10, pp. 30-43. 1999.

ROSSI FILHO, A., MERONI, A., MONTI, C. \& GALISAI, R. São Paulo Design Visions: Strategic design as an agent of dialog and transformation. Strategic Design Research Journal, Jul-Oct, 2(2), pp. 56-63. 2009.

SENAI, FIEMG, SEBRAE \& SINDMOB. Diagnóstico empresarial das industrias moveleiras de Uberlândia e Região. Uberlândia: Sistema FIEMG. Pool Comunicação. 2006

SWAN, J., NEWELL, S., SCARBROUGH, H., \& HISLOP, D. 1999. Knowledge management and innovation: networks and networking. Journal of Knowledge Management, 3(4), 262-275. 1999

TOMAEL, M., ALCARA, A., \& DI CHIARA, I. Das redes socias à inovação. Ci. Inf., Brasilia, 34(2), 93104. 2005

TSAI, K. Collaborative networks and product innovation performance: toward a contingency perspective. Research Policy, Volume 38, pp. 765-778. 2009.

VAN DE VEN, A. Central problems in the Management of Innovation. Management Science v.32, n.5, p. 590-607. 1986

VAN DEN BOSCH, S., \& ROTMANS, J. Deepening, Broadening and Scaling up. A framework for Steering Transition Experiments. Knowledge Centre for Sustainable System, Innovations and Transitions (KCT). 2008

VEZZOLI, C. System Design for Sustainability. Theory, methods and tools for a sustainable "satisfaction-system" design (Ottobre ed.). Maggiore Editore, S.p.S. 2007

WORD ECONOMIC FORUM. Towards the circular economy: accelerating the scale-up across global supply chains. Presented at World Economic Forum, Geneva, Switzerland. 2014

ZURLO, F., 1999. Un modello di lettura per il Design Strategico: La relazione tra design e strategia dell'impresa contemporanea. Milano: Doctorate Thesis. Dipartimento INDACO. Politecnico di Milano.

ZURLO, F., 2012. La strategia del design. Disegnare il valore oltre il prodotto. Milano: Libraccio Editore. 